\begin{tabular}{|c|c|}
\hline 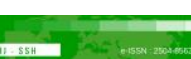 & Malaysian Journal of Social Sciences and Humanities (MJSSH) \\
\hline $\begin{array}{l}\text { Malaysian Journal of } \\
\text { Socialsciences and } \\
\text { Humantites }\end{array}$ & $\begin{array}{c}\text { Volume 6, Issue 6, June } 2021 \\
\text { e-ISSN : 2504-8562 }\end{array}$ \\
\hline (MJ-SSH) & $\begin{array}{l}\text { Journal home page: } \\
\text { www.msocialsciences.com }\end{array}$ \\
\hline
\end{tabular}

\title{
Penggunaan Aplikasi Pembelajaran Mudah Alih dalam Pembelajaran Matematik bagi Pelajar Sekolah Menengah
}

\author{
Nur Hafizah Binti Razali1, Fariza Binti Khalid1 \\ ${ }^{1}$ Fakulti Pendidikan, Universiti Kebangsaan Malaysia (UKM) \\ Correspondence: Nur Hafizah Binti Razali (fyzahrazaly@gmail.com)
}

\begin{abstract}
Abstrak
Penggunaan aplikasi untuk peranti mudah alih telah berkembang dengan pesat dan menjadi isu yang hangat diperkatakan dalam bidang pendidikan serta perkembangan pelajar. Fleksibiliti, mesra pengguna, kecil, kemudahan akses dan pelbagai keupayaan teknologi mudah alih yang lain menjadikannya berharga dan menjadi keperluan pada masa kini. Kajian ini adalah bertujuan untuk mengenal pasti pelajar sekolah menengah menggunakan aplikasi mudah alih bagi subjek matematik dalam pembelajaran secara kendiri melalui satu kajian kes. Kajian ini dilaksanakan di sebuah sekolah menengah di Terengganu. Pengumpulan data juga dilakukan dengan menggunakan instrumen temu bual kepada 10 orang pelajar daripada populasi 233 orang pelajar sekolah menengah di Terengganu. Hasilnya menunjukkan terdapat perbezaan pembelajaran secara kendiri bagi pelajar lelaki dan perempuan dalam penggunaan aplikasi mudah alih. Oleh itu, pelajar sekolah menengah masih perlu diberikan pengetahuan dan motivasi mengenai pembelajaran secara kendiri kerana penggunaan teknologi seperti aplikasi mudah alih dalam pengajaran dan pembelajaran adalah salah satu strategi pengajaran untuk perkembangan kemahiran metakognisi dalam penyelesaian masalah matematik.
\end{abstract}

Kata kunci: aplikasi mudah alih, pembelajaran kendiri, matematik, sekolah menengah, pendidikan

\section{Use of Mobile Learning Applications in Mathematics for Secondary School Students}

\begin{abstract}
The use of applications for mobile devices has grown rapidly and has become a hotly debated issue in the field of education as well as student development. Flexibility, user-friendly, small, easy access and various other mobile technology capabilities make it valuable and a necessity nowadays. This study aims to identify high school students using mobile applications for mathematics subjects in self-learning through a case study. This study was conducted in a secondary school in Terengganu. Data collection was also done using interview instruments to 10 students from a population of 233 secondary school students in Terengganu. The results show that there are differences in self-learning for male and female students in the use of mobile applications. Therefore, high school students still need to be given knowledge and motivation about self-learning because the use of technology such as mobile applications in teaching and learning is one of the teaching strategies for the development of metacognitive skills in solving mathematical problems.
\end{abstract}

Keywords: mobile applications, self-learning, mathematics, secondary school, education 


\section{Pengenalan}

Ramai pelajar mempunyai perspektif negatif mengenai kesukaran matematik sebagai subjek sekolah, dan salah faham ini ditambah dengan penggunaan strategi pengajaran yang tidak meningkatkan penguasaan matematik di kalangan pelajar (Iji, Abah \& Anyor, 2017). Sumber keprihatinan di kalangan pendidik matematik telah mendorong pencarian penyelesaian teknologi yang diperkembangkan untuk penyampaian instruksional. Matematik memerlukan pengembangan dan penguasaan prosedur penyelesaian masalah. Prosedur sedemikian melibatkan, manipulasi yang mahir, logik akal dan pendekatan yang berhati-hati untuk memastikan ketepatan (Iji, Abah \& Uka, 2013). Fakta ini adalah petunjuk yang jelas bahawa untuk membina hasil yang baik dalam pendidikan matematik, diperlukan strategi penyampaian yang berkesan. Penyampaian strategi pengajaran yang berkesan mungkin disokong oleh teknologi Pendidikan kerana membolehkan pelajar memilih bagaimana mereka belajar dan guru pula bertindak sebagai pembimbing, bukannya mengarah.

Oleh itu, Keperluan untuk pembelajaran berterusan dalam masyarakat hari ini tidak dapat dinafikan dalam menghadapi kemajuan teknologi yang mesti diketahui dan disokong oleh para profesional, penggunaan teknologi maklumat yang digunakan dengan tepat dapat menjadi alat yang efektif untuk memenuhi keperluan ini dengan menyediakan bentuk pembelajaran dan latihan berasaskan internet yang dinamik dan interaktif (Haag, 2011). Sebagai contoh, penggunaan peranti mudah alih ia menambah peluang untuk bentuk pedagogi yang inovatif dan kurang ketat daripada bentuk pengajaran-pembelajaran teknologi menengah yang lain (Sharpless, Taylor \& Vavoula, 2007).

Aplikasi mudah alih merupakan aplikasi perisian yang dibangunkan khusus untuk digunakan pada peranti pengkomputeran kecil, seperti telefon pintar dan tablet, bukan untuk komputer meja atau komputer riba. Aplikasi mudah alih boleh merangsang penglibatan pelajar menerusi aktiviti berorientasikan pengetahuan. Pembelajaran mudah alih melalui aplikasi mudah alih dalam pendidikan merangsang motivasi pelajar untuk belajar secara kendiri kerana peralatan mudah alih seperti telefon pintar amat mudah digunakan dan mempunyai ciri-ciri yang menarik. Dengan cara ini, pelajar dapat mengambil bahagian dalam kursus dan akses bahan kajian, perundingan di luar waktu kelas atau infrastruktur tetap, dan mempunyai fleksibiliti penggunaan yang lebih besar untuk berinteraksi dengan rakan sebaya dalam masa nyata (Laurillard, 2007). Ini menggalakkan pelajar untuk belajar secara kendiri dalam ruang kesediaan mental dan fizikal pelajar (Saedah, 2004). Menurut Kamus Dewan "pembelajaran kendiri" membawa maksud situasi pembelajaran yang membolehkan pelajar belajar mengikut kadar kebolehan kendiri.

Kemajuan teknologi komunikasi baru telah menyumbang kepada peningkatan saling keterkaitan dan saling bergantung di seluruh dunia (Li, 2013; Poushter, 2016). Teknologi mudah alih boleh menyediakan peluang pendidikan pada bila-bila masa dan di mana sahaja melalui pelbagai fungsi (Crompton, 2013) namun, sebagai Pendidikan, Ilmiah PBB, dan Organisasi Budaya (UNESCO) menyatakan, peranti mudah alih tidak digunakan seefektifnya mungkin untuk memperbaiki masalah global dalam pendidikan (West, M., 2012). Penggunaan teknologi mudah alih yang berjaya dalam pendidikan memerlukan tenaga pengajar yang merancang pengalaman pembelajaran yang memanfaatkan kemampuan peranti mudah alih (Krull \& Duart, 2017).

Peranti mudah alih cenderung mendorong peluang penyelidikan baru dalam pembelajaran mudah alih kerana kadar perubahan teknologi. Selain peranti, teknologi komunikasi juga berubah, berubah fokus penyelidikan (Parsons, 2014). Sebagai contoh, media sosial dan "aplikasi" pesanan mesej adalah perkara biasa. Perkembangan dan corak penggunaan teknologi mudah alih dalam pendidikan berubah dengan cepat. Tujuan dan kaedah penyelidikan yang digunakan dalam kajian penting kerana mempengaruhi bagaimana hasil penyelidikan dikongsi, ditafsirkan dan digunakan (Wingkvist \& Ericsson, 2011). Kajian tinjauan dapat membantu mengenal pasti kemajuan di lapangan dan menawarkan garis panduan untuk merancang penyelidikan masa depan (Frohberg, Göth, \& Schwabe, 2009).

Memahami penggunaan aplikasi mudah alih kepada pelajar bagi subjek matematik dalam kajian penyelidikan juga dapat membantu pembuat dasar pendidikan dalam membuat keputusan mengenai teknologi dan pengajaran dan pembelajaran (Wu et al., 2012). Norlaila, Rosseni dan Mohammed (2020) 
mencadangkan bagi membuka peluang kepada para pendidik di sekolah rendah dan menengah untuk membina aplikasi mudah alih dengan menghasilkan modul pembelajaran tambahan kepada bahan rujukan sedia ada seperti buku teks.

Makalah ini memberikan tinjauan sistematik mengenai kajian pembelajaran mudah alih di pengajian tinggi dari tahun 2011 hingga 2015. Ia dimulakan dengan analisis kajian tinjauan sebelumnya untuk memberikan asas perbandingan dengan kajian serupa. Tujuan dan persoalan kajian kemudian dihuraikan. Bahagian seterusnya membincangkan metodologi yang digunakan untuk menjalankan kajian tinjauan. Ini diikuti dengan pembentangan hasil dapatan kajian, dengan perbandingan dengan beberapa kajian sebelumnya. Bahagian terakhir memberikan perbincangan mengenai penemuan kajian tinjauan.

Sejumlah kajian tinjauan telah dilakukan dalam beberapa tahun kebelakangan ini dalam usaha untuk meneroka dan memberikan pandangan mengenai pengetahuan yang semakin meningkat dalam pembelajaran mudah alih. Berdasarkan kajian literatur menunjukkan terdapat tiga jurang yang dikenal pasti dalam tinjauan sistematik ini. Pertama kebanyakan kajian dilakukan di prasekolah berbanding peringkat sekolah menengah, maka pada peringkat pendidikan yang lain masih memerlukan lebih banyak penyelidikan. Kedua, untuk mengelakkan penyelidik atau pihak berkepentingan lain mengulangi usaha yang tidak berjaya, laporan hasil kajian pembelajaran yang negatif juga perlu dilaporkan dan tidak hanya laporan yang positif. Ketiga, hasil kajian yang dikaji, jumlah yang besar penyelidik tidak mengenal pasti konsep matematik dan hanya dalam bidang matematik tertentu yang diajar sahaja. Adalah berguna untuk maklumat ini dinyatakan untuk memberitahu amalan supaya aplikasi mudah alih dapat meningkatkan kemahiran metakognitif pelajar.

Pada masa yang sama, pembelajaran menggunakan peranti mudah alih pendidikan ini dapat memotivasikan mereka dan memberikan pengalaman pembelajaran yang lebih berkesan dan menyeronokkan. Ini telah membuktikan bahawa penggunaan teknologi pembelajaran mudah alih dapat meningkatkan penyampaian pendidikan berkualiti yang berpusatkan pelajar. Selain itu, supaya penyelidikan ini dapat menyumbang ke arah pendidikan abad ke-21. Seperti yang dinyatakan dalam Pelan Pembangunan Pendidikan Nasional (Kementerian Pendidikan, 2013), dalam mendapatkan aspirasi pelajar dalam kemahiran berfikir, peralatan dan alat bantu mengajar harus sesuai dengan keperluan semasa. Tujuan kajian ini adalah untuk mengenal pasti bagaimana pelajar sekolah menengah menggunakan aplikasi mudah alih bagi subjek matematik dan penggunanya dalam pembelajaran secara kendiri. Oleh itu penyelidik telah melaksanakan satu kajian mengenai penggunaan aplikasi pembelajaran mudah alih dalam pembelajaran matematik. Secara spesifiknya (objektif) kajian ini akan:

i. Mengenal pasti kelebihan aplikasi pembelajaran mudah alih terhadap pembelajaran pelajar bagi subjek matematik sekolah menengah.

ii. Mengenal pasti kesan penggunaan aplikasi pembelajaran mudah alih terhadap pembelajaran kendiri.

\section{Sorotan Literatur}

\section{Pendekatan aplikasi mudah alih pendidikan dalam menyelesaikan masalah matematik}

Perkembangan teknologi mudah alih merupakan satu fenomena yang sering diperhatikan di seluruh dunia kerana jumlah langganan mudah alih telah menunjukkan pertumbuhan yang sangat pesat (Tsinakos, 2013). Kelebihan peranti mudah alih adalah kemudahan mengakses internet dari mana sahaja dan bila-bila masa (Adi Nur Cahyono \& Miftahudin, 2018). Pada masa ini, banyak aplikasi mudah alih telah dikembangkan bertujuan untuk belajar dalam pelbagai bidang pengetahuan (Oranç \& Küntay, 2019). Penambahan inisiatif secara meluas mengenai penggunaan teknologi dan aplikasi mudah alih untuk tujuan pendidikan telah dilancarkan (Kearney, Burden, \& Rai, 2015) kerana peningkatan penggunaan aplikasi dalam pelbagai aspek kehidupan disebabkan oleh keperluan individu terhadap telefon pintar seperti komunikasi, hiburan, produktiviti, perjalanan, dan pembelajaran serta harganya 
yang berpatutan. Bagi melahirkan masyarakat yang berpengetahuan, kreatif, berkebolehan secara digital dan kemahiran yang fleksibel, perlu menerapkan penggunaan teknologi di dalam pendidikan di sekolah (Ainley, 2010; Sharples et al., 2016).

Secara umum, teknologi mudah alih telah digunakan di kelas matematik lebih dari satu dekad. Pembelajaran matematik dibantu oleh aplikasi mudah alih dapat meningkatkan motivasi pelajar dalam pembelajaran, sehingga dapat meningkatkan logic dalam penyelesaian masalah matematik (Vidermanova \& Vallo, 2015, Bradley dan Holley (2011), dan kemahiran menyelesaikan masalah matematik serta aktiviti pendidikan yang dirancang dengan teliti dengan penggunaan aplikasi mudah alih juga dapat meningkatkan prestasi pelajar (Papadakis et al., 2016c). Penyelidikan Cahyono dan Ludwig (2018) juga menyatakan bahawa pelajar dapat belajar lebih banyak dalam menyelesaikan masalah melalui penggunaan teknologi. Berdasarkan kajian yang dilakukan oleh Su (2012) menyatakan bahawa teknologi mudah alih atau gamifikasi menjadi proses pembelajaran yang dapat mencapai prestasi pembelajaran yang lebih baik dan tahap motivasi yang lebih tinggi daripada pengajaran tradisional.

Ini juga sejajar dengan Nasution (2016), yang menyatakan bahawa strategi pembelajaran berdasarkan aplikasi mudah alih lebih interaktif, menyeronokkan, dan sangat berkesan dalam mencapai objektif pembelajaran. Ini ditunjukkan oleh hasil penyelidikan menurut Gharini (2015), aplikasi mudah alih memenuhi aspek yang sah, praktikal, dan berkesan yang ditunjukkan oleh tindak balas pelajar sekolah menengah dan hasil ujian pembelajaran pelajar dengan peratusan purata $96.33 \%$. Oleh itu, teknologi pembelajaran Mobile mempunyai potensi besar kerana pelajar dapat meningkatkan pengetahuan, kemahiran dan prestasi pembelajaran secara tidak formal melalui teknologi komunikasi (Hwang \& Wu, 2012, Camilleri \& Camilleri, 2017, Ciampa, 2014.). Secara langsung, persekitaran pembelajaran Mobile dapat mendorong pelajar untuk terlibat dalam proses penyelesaian masalah yang lebih mendalam, menyimpulkan bahawa lebih banyak penglibatan dalam aktiviti pembelajaran menggunakan aplikasi mudah alih dapat meningkatkan kecekapan teras pelajar abad ke-21, seperti komunikasi, penyelesaian masalah yang kompleks, dan kreativiti (Lai \& Hwang, 2014).

Beberapa pengarang telah mengkaji sejarah peningkatan dalam m-Learning atau aplikasi mudah alih pendidikan selama dekad yang lalu (Crompton, 2013; Parsons, 2014), dengan tinjauan literatur khusus yang berusaha menangkap aspek tertentu bidang ini (Parsons, 2014; Frohberg, Göth \& Schwabe, 2009; Naismith et al., 2004; Wingkvist \& Ericsson, 2011). Terdapat tinjauan literatur mengenai aplikasi mudah alih m-pembelajaran. Hasil tinjauan literatur dari analisis dengan menyenaraikan kajian yang telah menilai penggunaan aplikasi pendidikan untuk pembelajaran ditunjukkan dalam Jadual 1.

Tinjauan ini, telah memfokuskan tahap pendidikan pada kajian di mana aplikasi diperiksa untuk digunakan hanya pelajar yang berumur 12 hingga18 tahun iaitu di peringkat sekolah menengah. Pembangunan Mobile app menumpukan pada tahap persekolahan ini kerana bukti kurangnya penglibatan pelajar dalam sains dan matematik pada tahun kebelakangan ini (Palmer, Burke \& Aubusson, 2017; Ainley, Kos, \& Nicholas, 2008). Oleh itu, menyiasat bagaimana penggunaan Mobile app dapat mengoptimumkan pembelajaran dalam disiplin ini di sekolah menengah adalah sangat penting. Ini membatasi skop penyelidik berbanding dengan tinjauan yang ada. Manakala, skop subjek yang telah dipilih dengan memfokuskan untuk mencari kajian empirikal yang melaporkan aplikasi mudah alih dalam pendidikan matematik (Crompton \& Burke, 2015).

Beberapa ulasan yang ada mengenai topik ini iaitu konsep Matematik, Tahap Pendidikan, dan Konteks Pendidikan. Crompton dan Burke (2015) menyatakan aplikasi mudah alih Pendidikan kurang menekankan konsep matematik dikenal pasti, walaupun kebiasaannya tahap pendidikan ditunjukkan kerana penyelidik berpendapat bahawa mungkin kajian lepas fokuskan pengembangan kebolehan dan kemahiran ke semua bidang matematik dan tidak hanya membatasi ke dalam bidang matematik tertentu sahaja. Hal ini juga dapat disimpulkan bahawa fokusnya adalah pada teknologi yang digunakan manakala matematik bukanlah fokus utama kajian. Pembelajaran aplikasi mudah alih paling kerap digunakan dalam tetapan matematik sekolah rendah (34\%) diikuti oleh sekolah menengah (29\%) (Crompton \& Burke, 2015). Ini adalah perbezaan yang menarik dari penemuan Hwang dan Wu (2012). Dalam tinjauan literatur mereka mengenai pembelajaran mudah alih di semua mata pelajaran, mereka mendapati pendidikan tinggi menjadi konteks yang paling kerap untuk kajian pembelajaran mudah alih. Walau 
bagaimanapun, apabila tumpuannya adalah pada matematik, penyelidikan itu dilakukan terutamanya dalam suasana dasar.

\section{Metod Kajian}

Kajian ini menggunakan pendekatan kualitatif dengan pemilihan reka bentuk kajian kes. Tujuan kajian ini adalah untuk menilai bagaimana pelajar sekolah menengah menggunakan aplikasi mudah alih bagi subjek matematik dan penggunaannya dalam pembelajaran secara kendiri. Untuk tujuan ini, penyelidik menggunakan instrumen temu bual. Instrumen temu bual ini dihasilkan berdasarkan teori pembelajaran kendiri. Kaedah temu bual ini di mana subjek dan penyelidik hadir sama dalam proses memperoleh maklumat. Ia merupakan satu kaedah yang amat berkesan untuk meninjau persepsi seseorang, termasuk sikap, minat, pemikiran, nilai dan pendapatnya. Temu bual melibatkan perbualan antara penyelidik dengan peserta kajian untuk memperoleh maklumat yang relevan dengan kajian ini. Temu bual merupakan satu kaedah yang membolehkan seseorang penyelidik memperoleh maklumat kajian secara mendalam kerana ia melibatkan hubungan bersemuka secara langsung dengan peserta kajian (McNiff, 2002). Peserta kajian yang terlibat dalam kajian ini adalah 10 orang pelajar daripada populasi 233 orang pelajar tingkatan dua di sebuah sekolah menengah di Terengganu. Ciri-ciri pemilihan peserta kajian ialah mereka merupakan pelajar sekolah menengah yang mempunyai telefon pintar dan tablet sendiri, mempunyai rangkaian internet di rumah dan mereka juga bukan dari kalangan pelajar pandai. Penyelidik telah mendapat persetujuan daripada mereka untuk menjadi peserta kajian secara sukarela bagi kajian ini semasa pertemuan pertama diadakan. Pemerhatian dan analisis dokumen untuk menyokong dapatan kajian bagi kajian ini turut digunakan pada awal pengumpulan data kajian.

\section{Hasil Kajian}

Soalan separuh berstruktur tentang kelebihan aplikasi pembelajaran mudah alih terhadap pembelajaran pelajar sekolah menengah bagi subjek matematik. Jadual 1 menunjukkan ringkasan dapatan keseluruhan bagi kelebihan tersebut.

Jadual 1: Ringkasan Kelebihan Aplikasi

\begin{tabular}{llll}
\hline TEMA & KODE & $\mathbf{N}$ & $(\mathbf{\%})$ \\
\hline Mudah & a1) Senang & 4 & 40 \\
Tidak bosan & b1) Bosan & 8 & 80 \\
Elemen multimedia & b2) fokus & & \\
& c1) Banyak benda ada & 7 & 70 \\
& c2) Video & & \\
& c3) Bunyi & & \\
& c4) kuiz & & \\
\hline
\end{tabular}

Jadual 1 di atas menujukan hasil dapatan yang diperoleh mengenai kelebihan aplikasi pembelajaran mudah alih dalam pembelajaran pelajar sekolah menengah bagi subjek matematik. Berdasarkan analisis data yang dilakukan menunjukkan wujud empat tema kelebihan penggunaan aplikasi pembelajaran mudah alih terhadap pembelajaran pelajar.

\section{Mudah}

Tema pertama mengenai kelebihan aplikasi pembelajaran mudah alih adalah mudah. Berdasarkan jadual 2 ringkasan di atas menunjukkan 50\% daripada pelajar menyatakan bahawa penggunaan aplikasi pembelajaran ini memudahkan mereka dalam pembelajaran seperti membuat latihan pengukuhan. Justeru itu, pelajar dikehendaki menggunakan buku latihan untuk menulis tetapi jika menggunakan 
DOI: https://doi.org/10.47405/mjssh.v6i6.812

aplikasi pembelajaran mudah alih ini mereka hanya perlu klik sahaja butang yang disediakan bagi menjawab soalan. Contoh petikan temu bual ini seperti berikut :

"Lebih mudah kalau dalam buku nak buat latihan kene tulis kalau guna ni tekan je." (p1: cahya)

\section{Tidak bosan}

Tema kedua yang wujud dalam kelebihan aplikasi pembelajaran ini adalah tidak membosankan. Jadual di atas menunjukkan $80 \%$ pelajar menyatakan aplikasi pembelajaran ini tidak membosankan berbanding penggunaan buku teks. Menurut seorang daripada enam orang pelajar menyatakan bahawa penggunaan buku teks lebih cepat bosan dan tidak fokus. Berikut adalah contoh petikan temu bual:

"Guna aplikasi ni la, kalau baca buku ye cepat bosan cepat mengatuk, cepat tidak fokus." (p4: Dalia)

\section{Elemen Multimedia}

Seterusnya bagi tema ketiga adalah elemen multimedia. Hasil menunjukkan $70 \%$ pelajar menyatakan aplikasi pembelajaran mudah alih ini mempunyai elemen multimedia yang menarik manakala $30 \%$ lagi lebih menyukai aplikasi ini berbentuk permainan. Seramai tujuh pelajar memberitahu aplikasi ini mempunyai elemen multimedia iaitu animasi, grafik dan audio yang interaktif. Sebagai contoh petikan temu bual ini adalah berikut :

"Aplikasi macam ni, ye boleh cari jawapan, aplikasi ni ada gambar gerak-gerak, bunyi, muzik ada kuiz tekan je tidak perlu salin dah tapi macam tu la." (l3:Hafiz)

Soalan separuh berstruktur tentang penggunaan aplikasi pembelajaran mudah alih dalam pembelajaran secara kendiri pelajar sekolah menengah. Jadual 2 menunjukkan ringkasan dapatan keseluruhan mengenai pembelajaran secara kendiri.

Jadual 2: Ringkasan Pembelajaran Kendiri

\begin{tabular}{|c|c|c|c|}
\hline TEMA & KODING & $\mathbf{N}$ & $(\%)$ \\
\hline \multirow[t]{5}{*}{ Mengenai Aplikasi } & a1) Menarik & 10 & 100 \\
\hline & a2) Minat & 5 & 50 \\
\hline & a3) Suka & & \\
\hline & a4) Sedap Guna & & \\
\hline & a5) tertarik & & \\
\hline \multirow[t]{2}{*}{ Motivasi } & b1) Semangat & 5 & 50 \\
\hline & b2) Rajin & & \\
\hline \multirow[t]{3}{*}{ Penyelesaian kendiri } & c1) Bertanya guru & 6 & 60 \\
\hline & c2) Guna aplikasi & 2 & \\
\hline & c3) Lihat formula & 1 & \\
\hline \multirow[t]{2}{*}{ Menggunakan Sendiri } & d1) Tekan Sendiri & 1 & 10 \\
\hline & d2) Boleh Guna & 9 & 90 \\
\hline \multirow[t]{2}{*}{ Pengetahuan Sedia Ada } & e1) Pernah Guna & 8 & 80 \\
\hline & e2) Tidak Pernah Guna & 2 & 20 \\
\hline \multirow[t]{2}{*}{ Sikap } & f1) Bergantung & 4 & 40 \\
\hline & f2) Tiada Usaha & 2 & 20 \\
\hline
\end{tabular}


Jadual 2 di atas menujukan hasil dapatan yang diperoleh mengenai kesan penggunaan aplikasi pembelajaran mudah alih terhadap pembelajaran kendiri pelajar sekolah menengah bagi subjek matematik. Berdasarkan analisis data yang dilakukan menunjukkan wujud lima tema kesan dalam penggunaan aplikasi pembelajaran mudah alih terhadap pembelajaran kendiri pelajar.

\section{Aplikasi yang menarik dan minat menggunakan aplikasi}

Tema pertama adalah mengenai aplikasi yang menarik dan minat menggunakannya. Hasil menunjukkan $100 \%$ pelajar menyatakan aplikasi pembelajaran mudah alih ini menarik tetapi hanya $50 \%$ yang berminat untuk menggunakan aplikasi ini dalam pembelajaran mereka. Sebagai contoh petikan temu bual ini menggambarkan tema aplikasi menarik dan penggunaannya :

"Aplikasi ni menarik tapi bila rosokan, teleponkan jadi susah semua dalam tu hilang tidak boleh buat apa-apa ar, jadi baik guna buku teks.” (l1: Fariz).

Selain itu, hanya lima orang pelajar perempuan memilih pembelajaran di luar kelas dengan menggunakan aplikasi mudah alih. Menurut dua daripada lima orang pelajar perempuan tersebut, mereka memilih pembelajaran menggunakan teknologi atau aplikasi yang menggunakan telefon pintar kerana ianya menyeronokkan dan pembelajaran menggunakan aplikasi atau elektronik ini telah menjadi pilihan masyarakat kini serta aplikasi ini juga lebih mudah dan jimat masa untuk mereka belajar dengan hanya klik sahaja butang dalam aplikasi tanpa memerlukan buku latihan untuk menulis kerana semuanya dah tersedia.

Begitu juga dengan penyataan salah seorang daripada lima orang pelajar perempuan menyatakan teknologi mudah alih mempunyai elemen yang menarik semasa menggunakan aplikasi berbanding buku teks contohnya kuiz yang terdapat dalam aplikasi mempunyai pilihan jawapan dan butang yang bergerak-gerak. Sebagai contoh petikan temu bual ini seperti berikut :

"Aplikasi mudah alih sebab dia menarik dari buku teks. kuiz tu ada pilihan jawapan, ada butang gerak-gerak.” (p1: Amina)

Tetapi bagi penyataan daripada dua orang pelajar lelaki menyatakan bahawa pelajar yang cemerlang ini lebih memilih atau suka pembelajaran dalam buku teks, buku teks ini banyak fakta dan dia juga memberitahu jika aplikasi ini dihasilkan berbentuk game (permainan) lagi menyeronokkan kerana baginya dalam game mempunyai ilusi gambar dan benda-benda yang menarik, seperti gambar bergerak dan berimaginasi serta permainan juga mempunyai point-point yang boleh dikumpulkan, jika terdapat juga pertandingan menjadikan permainan lebih menarik dan lebih bersemangat serta perlu ada komunikasi. Berikut merupakan contoh petikan temu bual :

"Bagi saya bagi pelajar yang cermelang ni buku teks ni suka buku teks ar, buku teks ni banyak fakta, aplikasi ni dalam game sedap $r$ sebab satu je dia ada gambar dan benda-benda yang menarik, ada gambar gerak dan berimajinasi macam tu ar. macam main mobile lengend tu ada pertandingan lagi sedap ar boleh cakap-cakap sambil buat tu boleh tanya cikgu, lebih semangat." (l4: Idris)

\section{Motivasi}

Tema kedua pula adalah kesan motivasi kepada pelajar. Hasil menunjukkan hanya $50 \%$ yang menyatakan penggunaan aplikasi mudah alih ini memberikan mereka motivasi dalam pembelajaran bagi matematik. Lima orang pelajar daripada sepuluh pelajar menyatakan aplikasi ini memberikan motivasi kepadanya untuk mudah belajar kerana telefon sentiasa dibawa bersamanya jika hendak belajar jadi mudah berbanding dengan belajar menggunakan buku, jika buku dan pelajar berada di tempat yang berbeza menyebabkan kesukaran untuk belajar. Berikut merupakan contoh petikan temu bual bagi tema motivasi : 
DOI: https://doi.org/10.47405/mjssh.v6i6.812

"Motivasi ar jadi rajin nak belajar, Kalau buku ye dekat lain kita dekat lain susah tapi kalau telpon ni ada dengan kite selalu senang ar." (p3: Cahya)

\section{Penyelesaian kendiri}

Seterusnya adalah tema ketiga iaitu cara penyelesaian kendiri. Berdasarkan jadual di atas mengenai masalah-masalah yang sering timbul bagi pembelajaran matematik dan cara penyelesaian yang dilakukan sebelum ini menunjukkan $60 \%$ daripada pelajar akan bertanya pada guru mereka manakala $20 \%$ lagi akan menggunakan aplikasi dan $10 \%$ sahaja yang merujuk formula. Hasil dapatan kajian ini mendapati enam daripada sepuluh orang pelajar adalah dengan menunggu kelas pada keesokan harinya untuk bertanya pada cikgu macam mana nak selesaikan soalan tersebut. Sebagai contoh petikan temu bual ini menggambarkan tema yang penyelesaian masalah :

\section{"Kalau saya biasa saya tunggu kelas esok baru tanya cikgu nak buat macam mana." (p2: Cahya)}

Selain itu, dua orang pelajar daripada sepuluh pelajar menggunakan teknologi bagi cara penyelesaian matematik, menurut mereka aplikasi yang digunakan bagi penyelesaian masalah matematik ini untuk mencari jawapan seperti imbasan soalan tersebut dengan menggunakan kamera telefon pintar, aplikasi tersebut adalah snapmath tetapi dengan menggunakan aplikasi snapmath ini akan memberikan jalan penyelesaian dengan menggunakan ayat yang tinggi dan sukar untuk memahami pengiraannya yang panjang. Berikut adalah contoh petikan temu bual ini :

"Saya guna teknologi untuk cari jawapan macam guna snapmath tapi gitu ar, yang ada tu tinggi sangat jadi jalan kira dia banyak lepas tu ayat-ayat dia tinggi nak faham." (p4: Dalia).

\section{Menggunakan sendiri}

Menggunakan sendiri tanpa bantuan orang lain adalah tema yang keempat dalam kajian ini. Oleh itu, hasil dapatan di atas menunjukkan kesemua pelajar bersamaan $100 \%$ boleh menggunakan aplikasi mudah alih ini tanpa bantuan orang lain kerana kesemua pelajar mempunyai pengalaman sedia ada menggunakan aplikasi tanpa bantuan orang lain. Pengalaman menggunakan aplikasi pembelajaran seperti snapmath dan photomath. Snapmath dan photomath ini digunakan untuk mencari jawapan dengan membuat imbasan pada soalan dan setelah soalan dikesan akan mengeluarkan jawapan. Berikut adalah contoh petikan temu bual menggambarkan tema yang menggunakan sendiri :

"Bagi saya, Boleh saya boleh guna tanpa bantuan orang lain,sebelum ni pernah
guna photomath dengan snapmath untuk cari jawapan tu ambil gambar soalan tu
kuar jawapan." (p3: Cahya) Pengetahuan Sedia Ada

Hanya lapan daripada sepuluh orang pelajar yang mempunyai pengetahuan sedia ada dalam penggunaan aplikasi pembelajaran sebelum ini manakala dua lagi tidak pernah menggunakan aplikasi pembelajaran tetapi mereka mempunyai pengalaman bermain game atas talian serta pelajar ini mempunyai pengalaman dalam pembelajaran atas talian seperti pernah menggunakan aplikasi quzzie, menurutnya guru akan memberikan link dan meminta mereka untuk menjawab soalan tetapi pelajar ini menyatakan quzzie tidak ada semakan jawapan betul diakhir dan hanya keluar markah sahaja, google meet turut digunakan semasa perintah kawalan pergerakan (PKP). Sebagai contoh petikan temu bual ini seperti berikut:

"Pernah guna quzzie, guru beri link untuk menjawab soalan lepas tu google meet guna masa PKP tetapi quzzie ni tidak boleh nak semak jawapan betul dan salah lepas hantar keluar markah je." (l2: Gazali) 


\section{Sikap}

Empat pelajar lebih memilih menggunakan aplikasi pembelajaran mudah alih berbanding pembelajaran melalui buku teks tetapi lima daripada sepuluh pelajar masih memerlukan bantuan guru semasa berlakunya sesi pengajaran dan pembelajaran, menurut seorang pelajar yang ditemu bual menyatakan aplikasi pembelajaran mudah alih ini lebih kepada belajar sendiri tetapi dia lebih menyukai belajar bersama-sama guru kerana apabila belajar sendiri akan menimbul perasaan malas dan tidak bersemangat untuk belajar yang melibatkan angka. Berikut adalah contoh petikan temu bual menggambarkan tema sikap :

“Aplikasi dalam telepon ni lebih kepada belajar sendiri tetapi tak sedap ar...saya lebih suka berlajar ada cikgu sebab bila belajar sendiri ini ada perasaan malas dan tidak semangat nak belajar nak-nak libatkan nombor." (l3: Hafiz)

Bagi mereka penggunaan aplikasi pembelajaran ini mudah tetapi untuk pembelajaran secara sendiri ini tidak dapat membantu mereka dalam menguasai topik matematik dan mereka memerlukan kehadiran guru secara bersemuka kerana bagi mereka subjek matematik ini tidak sama dengan subjek membaca yang hanya perlu menghafal. Sebagai contoh petikan temu bual ini seperti berikut:

\section{"Mudah guna aplikasi ni tapi dengan ada cikgu depan-depan lagi best la sebab matematik ni tidak sama macam subjek baca boleh hafal je kena ada cikgu juga." (p5: Ely)}

Terdapat salah satu daripada enam pelajar ini menyatakan bahawa dia suka menggunakan telefon pintar untuk bermain permainan ( game) sahaja dan bukan untuk belajar, jika belajar dia lebih memilih untuk belajar di dalam kelas bersama guru. Contoh petikan temu bual ini seperti berikut:

"Tidak ar, sedap main game dalam telefon ni kalau belajar dalam kelas perlu ada cikgu baru semangat nak belajar.” (13: Hafiz)

\section{Perbincangan Kajian}

\section{Penggunaan aplikasi pembelajaran mudah alih terhadap pandangan dan minat pelajar dalam pembelajaran matematik.}

Berdasarkan dapatan kajian yang di atas, didapati penggunaan aplikasi pembelajaran mudah alih ini mempunyai beberapa kelebihan kepada pelajar. Antara kelebihannya adalah $50 \%$ pelajar menyatakan aplikasi ini memudahkan mereka, $80 \%$ bersamaan 8 orang pelajar yang ditemu bual lebih suka menggunakan aplikasi ini kerana tidak membosankan berbanding buku teks. Seterusnya kelebihan aplikasi ini kerana ianya mempunyai elemen multimedia yang menarik seperti animasi, grafik, audio dan video pembelajaran yang interaktif berbanding aplikasi pembelajaran matematik yang lain. Menurut Praherdiono dan Adi (2008), kelebihan multimedia adalah menarik indera dan menarik minat karena menggabungkan antara pandangan, suara dan Gerakan, manakala kajian ini juga disokong oleh kajian Nie, Bird dan Edirishingha (2013) dalam kajian mereka di mana aplikasi seperti ini akan memberikan kelebihan dan memanfaatkan masa dengan lebih baik dalam mengakses bahan kursus.

Selain itu, responden perempuan mengenai pembelajaran dengan menggunakan aplikasi mudah alih ini adalah sangat sesuai dilakukan kerana telefon pintar telah menjadi pilihan oleh kebanyakan pelajar dalam aktiviti harian mereka kerana telefon pintar ini mempunyai elemen yang menarik perhatian serta meningkatkan emosi pelajar untuk belajar berbeza daripada buku teks. Bagi meningkatkan lagi emosi pelajar, aplikasi yang dihasilkan perlu dirancang dengan baik seperti dapatan yang diperoleh daripada tiga responden lelaki lebih berminat mengenai aplikasi pembelajaran yang berasaskan permainan, menurut mereka aplikasi yang membolehkan mereka untuk terus berkomunikasi dengan orang lain terutama guru seperti bermain permainan atas talian iaitu mobile lengend, belajar sambil bermain dan 
boleh bertanya cikgu akan lebih bersemangat serta mempunyai imajinasi dan ilusi gambar yang menarik. Kajian ini mempunyai persamaan dengan kajian Papadakis et al. (2016c) iaitu aktiviti pendidikan yang dirancang dengan teliti dengan penggunaan peranti mudah alih, meningkatkan motivasi dan prestasi pelajar.

Hal ini juga menunjukkan bahawa aplikasi pembelajaran mudah alih pada peringkat sekolah menengah sangat kurang dihasilkan berdasarkan hasil dapatan temu bual pelajar perempuan yang pernah menggunakan aplikasi pembelajaran ini menyatakan aplikasi yang pernah digunakan memberikan jalan penyelesaian dengan menggunakan ayat yang tinggi dan sukar untuk memahami pengiraannya yang panjang dan kebanyakan aplikasi yang ada lebih kepada mencari jawapan sahaja. Kajian ini sama dengan kajian Palmer, Burke, dan Aubusson (2017) mendapati bukti kurangnya penglibatan pelajar dalam matematik dan sains pada tahun kebelakangan ini dan pembangunan aplikasi mudah alih lebih menumpukan pada tahap persekolahan.

\section{Penggunaan aplikasi pembelajaran mudah alih terhadap pembelajaran kendiri.}

Kesemua responden telah terdedah kepada penggunaan aplikasi mudah alih sejak mereka di sekolah rendah dan mereka jelas menunjukkan bahawa pelajar sekolah menengah cukup akrab dengan teknologi mudah alih. Walau bagaimanapun, hanya pelajar perempuan dan satu pertiga pelajar lelaki menggunakan aplikasi mudah alih tujuan pendidikan, sementara selebihnya menggunakan aplikasi mudah alih ini hanya untuk alasan peribadi dan bermain game atas talian. Hal ini, menurut pelajar apabila melibatkan pembelajaran matematik mereka lebih menyukai belajar bersama guru kerana apabila belajar sendiri ini timbul perasaan malas dan tidak bersemangat untuk belajar. Oleh itu, penggunaan aplikasi pembelajaran mudah alih dalam pembelajaran secara kendiri pelajar sekolah menengah adalah sederhana lemah kerana beberapa aspek seperti pengetahuan sedia ada, penyelesaian kendiri, sikap, motivasi dan aplikasi itu sendiri.

Berdasarkan aspek mengenai aplikasi pembelajaran mudah alih yang menarik dan minat menggunakan aplikasi tersebut. Secara keseluruhannya pelajar menyatakan aplikasi pembelajaran mudah alih ini menarik kerana aplikasi ini menyeronokkan, mudah dan menjimatkan serta pembelajaran menggunakan aplikasi atau elektronik ini telah menjadi pilihan masyarakat kini di semua peringkat umur serta mempunyai fleksibiliti dari segi tempat dan masa. Dapatan kajian ini menyokong kajian Tsinakos (2013), dalam perkembangan teknologi mudah alih telah menjadi fenomena yang sering diperhatikan di seluruh dunia kerana jumlah langganan mudah alih telah menunjukkan pertumbuhan yang pesat. Begitu juga, dalam kajian Crompton (2013) menyatakan Teknologi mudah alih boleh memberikan peluang pendidikan pada bila-bila masa dan di mana sahaja melalui pelbagai fungsi. Tetapi hanya sebahagian pelajar yang berminat untuk menggunakan aplikasi mudah alih ini dalam pembelajaran mereka kerana mereka menyatakan bahawa pembelajaran matematik ini lebih baik belajar bersemuka bersama-sama guru.

Justeru itu, sikap pelajar memainkan peranan penting bagi pembelajaran secara kendiri. Ini adalah kerana sikap mereka yang masih bergantung pada guru dan tidak berusaha untuk melakukan sendiri walaupun tidak menggunakan teknologi, bahawa mereka tidak melakukan ulang kaji di rumah kecuali dengan latihan yang diberikan oleh guru. Begitu juga mengenai sikap dua orang responden apabila masalah dalam pengiraan matematik ini hanya membiarkan sahaja tanpa penyelesaian. Tindakkan individu yang dipengaruhi oleh sikap responden itu sendiri terhadap sesuatu perkara tersebut kerana pembelajaran kendiri ini memerlukan tindakan diri sendiri yang positif. Sedangkan kita perlu melatih menggunakan setiap teknologi dalam pendidikan di dalam zaman tanpa sempadan supaya guru dan pelajar tidak ketinggalan.

Kajian ini mempunyai persamaan dengan kajian Mohd Najib, Noor Raudhiah Abu Bakar and Norziah (2017) mengenai sikap individu yang positif sentiasa akan membawa kepada perilaku yang positif manakala, sikap individu yang negatif sentiasa akan membawa kepada perilaku yang negatif serta sikap individu itu sendiri yang menjadikan penggunaan aplikasi pembelajaran mudah alih ini sebagai satu kepentingan atau sebaliknya. Pembelajaran mudah alih ini memerlukan motivasi diri sendiri, dedikasi 
dan disiplin kerana penggunaan aplikasi mudah alih ini adalah berpandukan diri sendiri (Shiun, 2007, Najib et al., 2017).

Walau bagaimana pun kesemua pelajar perempuan yang ditemu bual memberikan tindak balas yang positif mengenai penggunaan aplikasi pembelajaran mudah alih ini dan sebelum ini juga mereka pernah menggunakan aplikasi pembelajaran yang lain bagi membantu mereka dalam pembelajaran matematik tanpa bantuan guru atau rakan sebaya, mereka mempunyai pengetahuan sedia. Hasil dapatan ini diperoleh berdasarkan penyataan mengenai penggunaan aplikasi quzzie sebagai latihan yang diberikan oleh guru, tetapi menurut mereka selepas selesai menjawab soalan mereka tidak boleh menyemak jawapan betul atau salah dan hanya keluar markah sahaja sedangkan dalam aplikasi quzzie pelajar boleh semak jawapan keseluruhan serta boleh melakukan fungsi-fungsi yang lain juga.

Dengan mengambil kira bahawa responden adalah remaja berusia 13 sehingga 15 tahun, kita dapat melihat bahawa banyak dari mereka mempunyai tahap pengetahuan yang baik tetapi tidak sempurna dan sebaliknya, terdapat juga banyak yang tidak mempunyai pengetahuan tentang literasi maklumat (Kosta Dolenc \& Andrej Šorgo, 2020). Penemuan ini juga sejajar dengan kajian OECD. (2019) bahawa hanya satu dari sepuluh orang pelajar berusia 15 tahun yang dapat membezakan antara fakta dan pendapat, walaupun terdapat banyak masa yang dihabiskan dalam talian.

Hasil penemuan ini juga, menemukan bahawa terdapat perbezaan antara pelajar lelaki dan perempuan mengenai penggunaan aplikasi mudah alih ini dalam pembelajaran. Pelajar perempuan lebih berfikiran terbuka mengenai penggunaan aplikasi mudah alih dan mereka boleh belajar secara kendiri tanpa bantuan guru, sebaliknya bagi pelajar lelaki masih bergantung kepada guru mereka. Bagaimanapun mereka perlu diberi latihan dalam kemahiran literasi maklumat bagi membantu mereka dalam menggunakan aplikasi pembelajaran mudah alih ini lebih baik pada masa akan datang.

Secara ringkasnya penggunaan aplikasi mudah alih dalam subjek matematik ini boleh membantu pelajar untuk melatih diri dalam pembelajaran secara kendiri dan memerlukan motivasi diri sendiri, dedikasi dan disiplin dalam diri individu tersebut serta perlunya menghasilkan aplikasi mudah alih yang lebih banyak di peringkat sekolah menengah kerana dengan adanya aplikasi pembelajaran ini dapat membantu menjadikan proses pengajaran dan pembelajaran menjadi lebih menarik dan fleksibel. Norlaila, Rosseni dan Mohammed (2020) juga mencadangkan untuk membuka peluang kepada para pendidik di sekolah rendah dan menengah untuk membina aplikasi mudah alih dengan menghasilkan modul pembelajaran tambahan kepada bahan rujukan sedia ada seperti buku teks.

\section{Kesimpulan}

Menurut kajian yang telah dibincangkan, penyelidik mendapati bahawa aplikasi pembelajaran mudah alih bagi subjek matematik ini merupakan alat aplikasi yang membantu proses pengajaran dan pembelajaran menjadi lebih fleksibel dan efektif. Oleh itu, pelajar sekolah menengah masih perlu diberikan pengetahuan literasi maklumat dan motivasi mengenai pembelajaran secara kendiri kerana penggunaan teknologi seperti aplikasi mudah alih dalam pengajaran dan pembelajaran adalah salah satu strategi pengajaran untuk perkembangan kemahiran metakognisi dalam penyelesaian masalah matematik. Bagaimanapun aplikasi pembelajaran mudah alih ini perlu ditambah baik pada masa akan datang mengikut peredaran dan keperluan semasa.

\section{Rujukan}

Ainley, J., Kos, J., \& Nicholas, M. (2008). Participation in science, mathematics and technology in Australian education. ACER Research Monographs, 4.

Ainley, J. (2010). Monitoring and assessing the use of ICT in education. Educational Research and Innovation, 67-88. 
Bradley, C. and Holley, D. (2011). Empirical research into students' mobile phones and their use for learning. International Journal of Mobile and Blended Learning (IJMBL), 3(4), 38-53.

Cahyono, A. N., \& Ludwig, M. (2018). Exploring mathematics outside the classroom with the help of GPS- enabled mobile phone application. Journal of Physics: Conference Series, 983, 1-7. https://doi.org/10.1088/1742-6596/983/1/012152

Camilleri, M.A. and Camilleri, A.C. (2017). Digital learning resources and ubiquitous technologies in education. Tech..Knowl. and Learning, 22(1), 65-82.

Ciampa, K. 2014. Learning in a mobile age: an investigation of student motivation. J. of Comp. Assisted Learning, 30(1), 82-96.

C. N, Din, R. \& Alias, M. H. (2020). Kesediaan pelajar tingkatan 6 menggunakan aplikasi mudah alih pendidikan. Journal of Personalized Learning, 3(1): 79-86.

Crompton, H. (2013). A historical overview of mobile learning: Toward learner-centered education. Handbook of Mobile Learning.

Crompton, H., \& Burke, D. (2015). Research trends in the use of mobile learning in mathematics. International Journal of Mobile and Blended Learning (IJMBL), 7(4),1-15.

Cahyono, Adi Nur. (2018). Learning Mathematics in a Mobile App-Supported Math Trail Environment. In SpringerBriefs in Education. https://doi.org/10.1007/978-3-319-93245-3

Frohberg, D., Göth, C., \& Schwabe, G. (2009). Mobile learning projects-a critical analysis of the state of the art. Journal of Computer Assisted Learning, 25(4), 307-331.

Gharini, I. \& Khabibah, S. (2015). Pengembangan Aplikasi Mobile Learning sebagai Media Pembelajaran Matematika untuk Materi Peluang. Jurnal Pendidikan Matematika FPMIPA UNNES.

Hwang, G.J. \& Wu, P.H. (2012). Advancements and trends in digital game-based learning research: a review of publications in selected journals from 2001 to 2010. Brit. J. of Educ. Tech. 43(1), E6E10.

Iji, C. O., Abah, J. A. \& Uka, N. K. (2013). Attaining the Millenium Development Goals (MDGs) through Effective Mathematics Education. Proceedings of the 54th Annual Conference of Science Teachers Association of Nigeria, 99-107.

Iji, C.O., Abah, J.A. \& Anyor, J.W. (2017). Impact of cloud services on students' attitude towards mathematics education in public universities in Benue State, Nigeria. International Journal of Research in Education and Science (IJRES), 3(1), 228-244. http://dergipark.ulakbim.gov.tr/ijres/article/download/5000202010/5000179858

Kosta Dolenc \& Andrej Šorgo (2020): Information literacy capabilities of lower secondary school students in Slovenia. The Journal of Educational Research, DOI: $10.1080 / 00220671.2020 .1825209$

Kearney, M., Burden, K., \& Rai, T. (2015). Investigating teachers' adoption of signature mobile pedagogies. Computers \& Education, 80, 48-57.

Krull, G., \& Duart, J. M. (2017). Research trends in mobile learning in higher education: A systematic review of articles (2011 - 2015). International Review of Research in Open and Distributed Learning, 18(7). http://dx.doi.org/10.19173/irrodl.v18i7.2893

Lai, C-L. and Hwang, G-J. (2014) 'Effects of mobile learning time on students' conception of collaboration, communication, complex problem-solving, meta-cognitive awareness and creativity', International Journal of Mobile Learning and Organisation, 8(3-4), 276-291.

Laurillard, D. (2007) 'Pedagogical forms of mobile learning: Framing research questions.' In Pachler, N. (ed.) Mobile learning: Towards a research agenda. London, WLE Centre, Institute of Education, pp. 153-176. Retrieved from http://www.wlecentre.ac.uk/cms/files/occasional papers/mobilelearning_pachler_2007.pdf

Li, Y. (2013). Cultivating student global competence: A pilot experimental study. Decision Sciences Journal of Innovative Education, 11(1). http://doi.org/10.1111/j.1540-4609.2012.00371.x

Mike Sharples, Josie Taylor, Giasemi Vavoula. A Theory of Learning for the Mobile Age. R. Andrews and C. Haythornthwaite. The Sage Handbook of Elearning Research, Sage publications, pp.221247, 2006. ffhal-00190276

Nasution, M. I, P. (2016). Strategi Pembelajaran Efektif Berbasis Mobile Learning Pada Sekolah Dasar. Jurnal Iqra', 1(1).

Naismith, L., Lonsdale, P., Vavoula, G. N., \& Sharples, M. (2004). Mobile technologies and learning. 
Najib, H. M., Bakar, N. R. A., \& Othman, N. (2017). E-Pembelajaran Dalam Kalangan Pelajar di Sebuah Institusi Pengajian Tinggi Selangor. Attarbawiy: Malaysian Online Journal of Education, 1(1), 74-82.

Nie, M., Bird, T., \& Edirisingha, P. (2013). E-book readers and PDAs for work-based learners. In Z. L. Berge \& L. Y. Muilenburg (Eds.), The handbook of mobile learning (pp. 209-223). New York: Routledge.

Oranç, C., \& Küntay, A. C. (2019). Learning from the real and the virtual worlds: Educational use of augmented reality in early childhood. International Journal of Child-Computer Interaction, (xxxx). https://doi.org/10.1016/j.ijcci.2019.06.002

OECD. (2019). PISA 2018 results (volume I): What students know and can do. PISA, OECD Publishing. https://doi.org/10.1787/5f07c754-enhttps://scihub.se/https://doi.org/10.1080/00220671.2020.1825209

Palmer, T.-A., Burke, P. F., \& Aubusson, P. (2017). Why school students choose and reject science: A study of the factors that students consider when selecting subjects. International Journal of Science Education, 39(6), 645-662.

Parsons, D. (2014). A mobile learning overview by timeline and mind map.

Praherdiono, H \& Adi, Pramono Eka. 2008. Panduan Praktikum Multimedia. Malang: Fakultas Ilmu Pendidikan Universitas Negeri Malang

Poushter, J. (2016, February 22). Smartphone ownership and internet usage continues to climb in emerging economies. The Pew Research Center. Retrieved from https://www.pewresearch.org/wpcontent/uploads/sites/2/2016/02/pew_research_center_global _technology_report_final_febru ary_22_2016.pdf R

Papadakis, S., Kalogiannakis, M. and Zaranis, N. (2016c). Developing fundamental programming concepts and computational thinking with ScratchJr in preschool education: a case study. International Journal of Mobile Learning and Organisation, 10(3), 187-202.

Su, C. (2012). A Mobile Gamification Learning System For Improving The Learning MotivationAnd Achievements. Journal of Computer Assisted Learning 31(2).

Siraj, S. (2004). Pembelajaran Mobile dalam Kurikulum Masa Depan [Mobile learning in future curriculum]. Masalah pendidikan, 27, 128-142.

Shiun, T. K. (2007). Kajian Mengenai Penggunaan E-Pembelajaran (E-Learning).

Tsinakos, A. (2013). State of mobile learning around the world. Global Mobile Learning Implementations and Trends, 4-44.

Vidermanova, K., \& Vallo, D. (2015). Practical Geometry Tasks as a Method for Teaching Active Learning in Geometry. Procedia - Social and Behavioral Sciences, 191, 1796-1800. https://doi.org/10.1016/j.sbspro.2015.04.421

Wingkvist, A., \& Ericsson, M. (2011). A survey of research methods and purposes in mobile learning. International Journal of Mobile and Blended Learning, 3(1), 1-17.

West, M. (2012). Turning on mobile learning: Global themes. UNESCO Working Paper Series on Mobile Learning. Retrieved from http://unesdoc.unesco.org/images/0021/002164/216451E.pdf

Wu, W. H., Jim Wu, Y. C., Chen, C. Y., Kao, H. Y., Lin, C. H., \& Huang, S. H. (2012). Review of trends from mobile learning studies: A meta-analysis. Computers and Education, 59(2), 817827. http://doi.org/10.1016/j.compedu.2012.03.016 